\title{
Lanthanum-exchanged zeolite and clay as anticorrosive pigments for galvanized steel
}

\author{
S. Roselli, N. Bellotti, C. Deyá, M. Revuelta, B. del Amo, R. Romagnoli \\ (CIDEPINT (Centro de Investigación y Desarrollo en Tecnología de Pinturas) (CONICET-CIC), Calle 52 entre 121 y 122 (B1900AYB) La Plata, Argentina)
}

Received 4 July 2013; revised 6 January 2014

\begin{abstract}
A wide variety of inhibitive pigments is now being offered as possible alternatives to chromate and lead compounds for painted metals protection. Unfortunately, the most wide spread of these substitute pigments, zinc phosphate, has, at present, raised some environmental concern because phosphate causes the eutrophication of water courses and zinc itself is toxic. The aim of this research was to study the anticorrosive performance of a mixture consisting of zinc phosphate, modified zeolite and clay (bentonite) in order to diminish phosphate content in paints. The zeolite and the clay were exchanged with La(III) ions, as inorganic green inhibitor. In the first step, the anticorrosion protection by $\mathrm{La}(\mathrm{III})$ ions in solution was assessed by electrochemical tests. In the second step, an epoxy-polyamide paint formulated with the pigment mixture applied on galvanized panels was studied by salt spray test and electrochemical noise measurements (ENM). The results showed that it was possible to replace part of the zinc phosphate content in the paint with the exchanged zeolite and the clay.
\end{abstract}

Keywords: exchanged pigments; corrosion; anticorrosive paints; electrochemical noise measurements; rare earths

A wide variety of inhibitive pigments is now being offered as possible alternatives to chromate and lead compounds for painted metals protection. Unfortunately, the most wide spread of these phosphate substitute pigments, zinc phosphate, has, at present, raised some environmental concern because it causes the eutrophication of water courses ${ }^{[1,2]}$. This process is originated by an excess of nutrients which produces changes in the biological community. An attempt to eliminate or, at least, diminish phosphate content in paints is one of the main focuses of the scientific research in this field. In this sense each component of the pigment system is carefully evaluated for its influence on the overall paint performance ${ }^{[3-5]}$. Particularly attention is given to silicate extenders, like talcs and clays. For example, the partial replacement ( $75 \%)$ of the corrosion inhibitor with surface modified clay improved the performance of paints formulated with basic lead silico chromate or zinc phosphate ${ }^{[4]}$. The performance of a synergistic blend of zinc phosphate and modified clay was comparable with that of strontium chromate and basic lead silico chromate ${ }^{[4]}$. Other researchers also studied the incorporation of polyaniline or quaternary alkylphosphonium salts in clays as anticorrosive pigments ${ }^{[6-8]}$.

The employment of extender pigments modified with rare earth metal (REM) cations such as cerium or lanthanum is of particular interest. Zeolites and bentonite are naturally occurring aluminosilicates. They share the capacity for ion-exchanging and may be employed as reservoirs for inhibitive cations. The use of a ceriumexchanged bentonite on galvanized steel has been reported by Bohm, et al. ${ }^{[9]}$. This exchanged-bentonite corrosion ability rests on the fact that it exchanged REM cations for $\mathrm{Na}^{+}$present in the attacking electrolyte.

REM salts may constitute alternative to phosphates as they are found to posses excellent inhibitive properties ${ }^{[10,11]}$. Lanthanum ions have proved to be efficient as corrosion inhibitor in chloride solutions of several metals ${ }^{[13]}$. The mechanism of operation of these inhibitors seems to be related with kinetic modifications of the cathodic reduction of oxygen ${ }^{[6]}$. Besides, lanthanide salts like nitrates were reported to have low toxicity comparable to that of sodium chloride ${ }^{[12]}$ and can be considered as "green" inhibitors.

Zeolites are crystalline-aluminosilicates which consist in an array of corner-sharing $\mathrm{SiO}_{4}^{-4}$ or $\mathrm{AlO}_{4}^{-5}$ tetrahedrals. These building blocks become arranged in a periodic way to form channels and cages with large specific surface areas, typically above $300 \mathrm{~m}^{2} / \mathrm{g}$, being the volume of internal voids above $0.1 \mathrm{~cm}^{3} / \mathrm{g}^{[12,14]}$. The aluminum ion is small enough to occupy the center of the tetrahedron of four oxygen atoms. The isomorphous replacement of $\mathrm{Si}^{4+}$ by $\mathrm{Al}^{3+}$ produces a negative charge in the lattice which could be balanced by the exchangeable cation. In previous studies, zeolites exchanged with mo-

Foundation item: Project supported by CONICET (Consejo Nacional de Investigaciones Científicas y Técnicas), UNLP (Universidad Nacional de La Plata) and CICPBA (Comisión de Investigaciones Científicas de la Provincia de Buenos Aires)

* Corresponding author: C. Deyá (E-mail: estelectro2@cidepint.gov.ar; Tel.: 54-0221-4831144)

DOI: $10.1016 / \mathrm{S} 1002-0721(14) 60078-8$ 
lybdenum were used to replace part of the zinc phosphate in smart anticorrosive paints ${ }^{[15]}$.

The aim of this research work was to study the anticorrosive performance of an epoxy-polyamide paint formulated with zinc phosphate, modified zeolite and clay (bentonite) applied on galvanized steel. The zeolite and the clay were exchanged with $\mathrm{La}(\mathrm{III})$ ions as inorganic green inhibitor. The anticorrosion protection by $\mathrm{La}$ (III) ions was assessed by electrochemical tests (corrosion potential, polarization resistance and polarization curves). Salt spray test and electrochemical noise measurements (ENM) were done on painted panels. The results showed that it was possible to replace part of the zinc phosphate content in the paint with exchanged zeolite and clay.

\section{Materials and methods}

\subsection{Minerals characterization}

The zeolite used in this research was extracted from Tasajera's reservoir in Cuba. The qualitative mineralogical composition was obtained by X-ray diffraction (XRD) in rock samples. The clay was a commercial one: Bentone $107^{\circledR}$, by Elementis. It was smectite clay, surface modified by an organic treatment ${ }^{[16]}$. The texture of the minerals was examined by scanning electron microscopy (SEM) in order to observe the morphology, surface structure and particles size.

The density of the natural zeolite and the commercial clay was obtained by a pycnometric method according to ASTM G 1475 to formulate the paints.

\subsection{Preparation of lanthanum-exchanged pigments}

The zeolitic rock was ground to obtain a fine grain powder with particles size less than $10 \mu \mathrm{m}$. The ground zeolite was washed with distilled water (DW) twice and placed in a beaker with $0.2 \mathrm{~mol} / \mathrm{L} \mathrm{HNO}_{3}$ which was heated up to the boiling temperature and kept at that temperature for $1 \mathrm{~h}$ in order to eliminate ferric compounds. The acid solution was added from time to time to keep the solution volume constant. The zeolite was separated from the supernatant by centrifugation at 2200 $\mathrm{X} \mathrm{g}$ for $10 \mathrm{~min}$ and washed with DW several times. Afterwards, it was placed in a beaker with $2 \mathrm{~mol} / \mathrm{L}$ $\mathrm{NaCH}_{3} \mathrm{COO}$ for $3 \mathrm{~h}$ under continuous stirring to put it back in the $\mathrm{Na}^{+}$-form. Then the zeolite was separated by centrifugation and washed with DW. Finally the zeolite was exchanged with $\mathrm{La}(\mathrm{III})$ ions by bringing it into contact with $1 \mathrm{~mol} / \mathrm{L} \mathrm{La}\left(\mathrm{NO}_{3}\right)_{3}$ in $1 \times 10^{-3} \mathrm{~mol} / \mathrm{L} \mathrm{HNO}_{3}$, under constant stirring, for $24 \mathrm{~h}$. The exchanged zeolite was separated by centrifugation, washed four times with DW and dried in an oven at $90{ }^{\circ} \mathrm{C}$. Similar procedure was done with the clay, except the milling pretreatment.

\subsection{Lanthanum-exchanged capacity}

The sorbed $\mathrm{La}$ (III) was back extracted into solution with $100 \mathrm{~mL}$ of $1 \mathrm{~mol} / \mathrm{L} \mathrm{CH}_{3} \mathrm{COONH}_{4}$ from $1 \mathrm{~g}$ of treated zeolite or bentonite by continuous stirring for 24 $\mathrm{h}$. Then the solid was separated by centrifugation and La was quantified in the supernatant by a gravimetric technique $^{[17]}$. Briefly, an aliquot of $70 \mathrm{~mL}$ of the solution containing lanthanum ion was acidified with $10 \mathrm{~mL}$ of 2 $\mathrm{mol} / \mathrm{L}$ acetic acid and treated with a slight excess of a $3 \%$ $(w / v)$ 8-hydroxyquinoline $\left(\mathrm{C}_{9} \mathrm{H}_{7} \mathrm{NO}\right)$ in ethyl alcohol. Then, lanthanum "oxinate" was precipitated by adding $20 \mathrm{~mL}$ of $10 \%(w / v)$ ammonium hydroxide and the solution was heated to boiling. The yellow precipitate was separated by centrifugation at $2200 \mathrm{X} \mathrm{g}$ for $5 \mathrm{~min}$, washed with hot water, dried at $110{ }^{\circ} \mathrm{C}$ and weighed in an analytical balance (precision $0.1 \mathrm{mg}$ ). The precipitated has the formula $\mathrm{La}\left(\mathrm{C}_{9} \mathrm{H}_{6} \mathrm{ON}\right)_{3}$ and contains $24.33 \mathrm{wt} . \%$ of lanthanum. The control sample was prepared with 70 $\mathrm{mL}$ of an aqueous solution of lanthanum nitrate containing $0.1 \mathrm{~g}$ of lanthanum ions.

\subsection{Electrochemical assays}

The protective behavior of $\mathrm{La}$ (III) ions was assessed by d.c. electrochemical techniques. Corrosion potential of commercial galvanized steel electrodes $\left(120 \mathrm{~g} / \mathrm{m}^{2}\right.$ of $\mathrm{Zn}$ ) was measured as a function of time with respect to the saturated calomel electrode (SCE). Lanthanum(III) nitrate concentration was varied from $3.3 \times 10^{-5}$ to $1.0 \times$ $10^{-2} \mathrm{~mol} / \mathrm{L}$. These solutions were employed in order to simulate the lanthanum concentration leached from zeolite or from the clay. The supporting electrolyte was $\mathrm{NaCl} 0.025 \mathrm{~mol} / \mathrm{L}$. Measurements were performed for $4 \mathrm{~h}$ and after $24 \mathrm{~h}$. Exposed panels were observed by SEM and the composition of the protective layer determined by EDX analysis.

Galvanized steel corrosion rate in the same electrolyte was obtained from polarization curves (with IR-drop compensation). A SCE and a platinum grid were used as reference and counterelectrode, respectively. The swept amplitude was $\pm 0.020 \mathrm{~V}$ from the open circuit potential and the scan rate $0.166 \mathrm{mV} / \mathrm{s}$. The area exposed was $0.28 \mathrm{~cm}^{2}$. Measurements were carried out with the 273A EG\&G PAR Potentiostat/Galvanostat in combination with model SOFTCORR 352 software (EG\&G PAR). Measurements were carried out after 2, 5 and $24 \mathrm{~h}$ of immersion.

\subsection{Formulation, elaboration and application of paints}

A bisphenol epoxy-polyamide resin $(1: 1$ ratio $v / v)$ was employed as the film forming material. The solvent was the mixture of xylene/methyl isobutyl ketone/butyl cellosolve $(13 / 45 / 42 \% w / w)$. Paints composition can be seen in Table 1. Paints labeled with $\mathrm{L}$ are the ones containing the exchanged zeolite while the ones labeled with $\mathrm{B}$ are the control paints containing the unexchanged zeo- 
Table 1 Paints composition as percentage by volume

\begin{tabular}{ccccccc}
\hline \multirow{2}{*}{ Components } & \multicolumn{7}{c}{ Paints } \\
\cline { 2 - 7 } & L1 & L2 & L3 & B1 & B2 & B3 \\
\hline Zeolite & 5.2 & 5.2 & 2.6 & 5.2 & 5.2 & - \\
Clay & - & - & 2.6 & - & - & - \\
Zinc phosphate & 2.6 & - & 2.6 & 2.6 & - & - \\
Barium sulfate & 7.4 & 8.5 & 7.4 & 7.4 & 8.5 & 10.7 \\
Talc & 7.4 & 8.5 & 7.4 & 7.4 & 8.5 & 10.7 \\
Titanium dioxide & 2.9 & 3.3 & 2.9 & 2.9 & 3.3 & 4.1 \\
Resin & 35.7 & 35.7 & 35.7 & 35.7 & 35.7 & 35.7 \\
Solvent & 38.8 & 38.8 & 38.8 & 38.8 & 38.8 & 38.8 \\
\hline
\end{tabular}

lite. Moreover, paints with number 1 contained zinc phosphate. Paint L3 had a certain amount of exchanged clay besides the exchanged zeolite and zinc phosphate. Barium sulfate, talc and titanium dioxide were incorporated to complete the pigment formulas. Paint B3 had only inert pigments (barium sulfate, talc and titanium oxide). In every case, the pigment volume concentration (PVC) was $41.2 \%$.

Pigments were dispersed in the vehicle (resin and solvent) for $24 \mathrm{~h}$, employing a ball mill, to achieve an acceptable dispersion degree.

Commercial galvanized steel panels $(15.0 \mathrm{~cm} \times 7.5 \mathrm{~cm} \times$ $0.2 \mathrm{~cm}$ ) were degreased firstly with toluene and, then, by immersion in boiling $5 \%(w / v) \mathrm{CaCO}_{3}$ for $5 \mathrm{~min}$. Then, the panels were washed with DW and dried. Previous to painting, panels were coated with a polyvinylbutiral wash primer pigmented with aluminium phosphosilicate. Details about this formulation and its performance may be found elsewhere ${ }^{[18]}$. Finally, panels were painted by brush, up to a dry film thickness of $65 \pm 5 \mu \mathrm{m}$, and were kept indoors for $14 \mathrm{~d}$ before testing.

\subsection{Accelerated and electrochemical tests on painted panels}

A set of three panels per paint was placed in a salt spray chamber (Atlas Model SF850, USA) in accordance with ASTM B 117 (Standard Method of Salt Spray (Fog) Testing). Rusting (ASTM D 610) and blistering (ASTM D 714) degrees were evaluated after $340,840,1536$, 1920 and $2350 \mathrm{~h}$ of exposure.

The ionic resistance between the coated steel substrate and a platinum electrode was measured in a cell obtained by fixing an acrylic tube, $2 \mathrm{~cm}$ diameter, on the painted specimen and filling it with $0.5 \mathrm{~mol} / \mathrm{L}$ sodium chloride. Measurements were carried out employing an ATI Orion, model 170, conductivity meter at $1000 \mathrm{~Hz}$.

The cell for ENM was constituted by two nominally identical electrodes and a reference electrode. A low value resistor was placed between the two specimens and current noise was measured through the voltage fluctuation across the resistor, on the grounds that interference from the electronic circuitry will be diminished. The three electrodes were in the same container which made it easier to control the effect of temperature fluctuations. The edges of the specimens were blanked off leaving 26 $\mathrm{cm}^{2}$ of the painted panel exposed to a $0.5 \mathrm{~mol} / \mathrm{L} \mathrm{NaCl}$ solution. Data were acquired with a NICOLET 310 digital oscilloscope and the corresponding software 310RFWFT. Adequate filtering was provided just to eliminate undesirable signals like line signals ${ }^{[19-21]}$. The sensitivity of the measuring device in the E-scale was $100 \mu \mathrm{V}$ and $100 \mathrm{nA}$ in current measurements. The sampling frequency was $5 \mathrm{~Hz}$, which is commonly used to study corroding systems ${ }^{[19-21]}$. Data were collected during $800 \mathrm{~s}$ and each data set was controlled to verify they distribute normally ${ }^{[22]}$. Statistical analysis of each time series were performed and the noise resistance $\left(R_{\mathrm{n}}\right)$ was calculated as the quotient $R_{\mathrm{n}}=\sigma_{\mathrm{E}} / \sigma_{\mathrm{i}}$, where $\sigma_{\mathrm{E}}$ is the dispersion of the potential data and $\sigma \mathrm{i}$ the dispersion of current density data ${ }^{[18-21]}$. Although the mean values of raw data were plotted, the d.c. trend was removed to perform $R_{\mathrm{n}}$ calculation by the moving average removal procedure described by Tan et al. ${ }^{[23]}$.

\section{Results and discussion}

\subsection{Characterization of the minerals}

Physical properties of the selected materials can be seen in Table 2. Tasajera's zeolite was composed of clinoptilolite, quartz and calcite: $\sim 30 \mathrm{wt} . \%$ of each mineral. Clay and plagioclase were also detected but in a lower low proportion (5 wt.\%-15 wt.\%). These results are similar to those reported in other studies ${ }^{[24,25]}$.

The SEM micrographs of the zeolite and the clay are shown in Fig. 1. It can be seen that the particle size distribution of both minerals, zeolite (Fig. 1(a)) and clay (Fig. 1(b)) was broad, with sizes varying from 6 to 100 $\mu \mathrm{m}$. Despite the bigger size of some particle $(>10 \mu \mathrm{m})$ as the materials were quite soft, no inhomogeneities appeared after painting the substrates.

\subsection{Lanthanum-exchanged capacity}

Table 2 shows that the exchange capacity of the zeolite, $10.90 \mathrm{mg}$ of $\mathrm{La}(\mathrm{III}) / \mathrm{g}$ mineral, was higher than that of the clay, $5.70 \mathrm{mg} / \mathrm{g}$ mineral. Results were also expressed as molar concentration in order to prepare the $\mathrm{La}$ (III) solutions for the electrochemical tests.

\subsection{Electrochemical assay}

Fig. 2 shows that the corrosion potential values were shifted from $\sim-0.970$ to $\sim-0.870 \mathrm{~V}$ when the $\mathrm{La}(\mathrm{III})$

Table 2 Physical properties of minerals

\begin{tabular}{|c|c|c|c|}
\hline \multirow{2}{*}{ Mineral } & \multirow{2}{*}{$\begin{array}{c}\text { Density/ } \\
(\mathrm{g} / \mathrm{mL})\end{array}$} & \multicolumn{2}{|c|}{ La-exchanged capacity } \\
\hline & & $\mathrm{mg} / \mathrm{g}_{\text {mineral }}$ & $\mathrm{mol} / \mathrm{L}$ \\
\hline Zeolite & 2.18 & $10.9 \pm 0.1$ & $7.8 \times 10^{-4}$ \\
\hline Clay & 1.70 & $5.7 \pm 0.4$ & $4.1 \times 10^{-4}$ \\
\hline
\end{tabular}



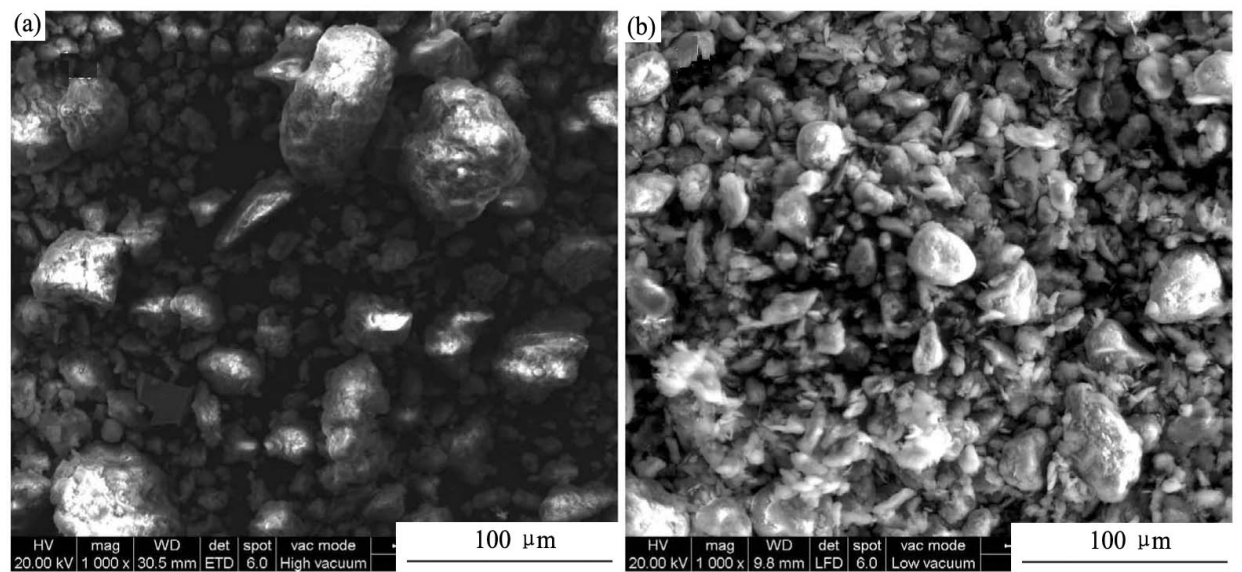

Fig. 1 Minerals SEM micrographs

(a) Zeolite; (b) Clay

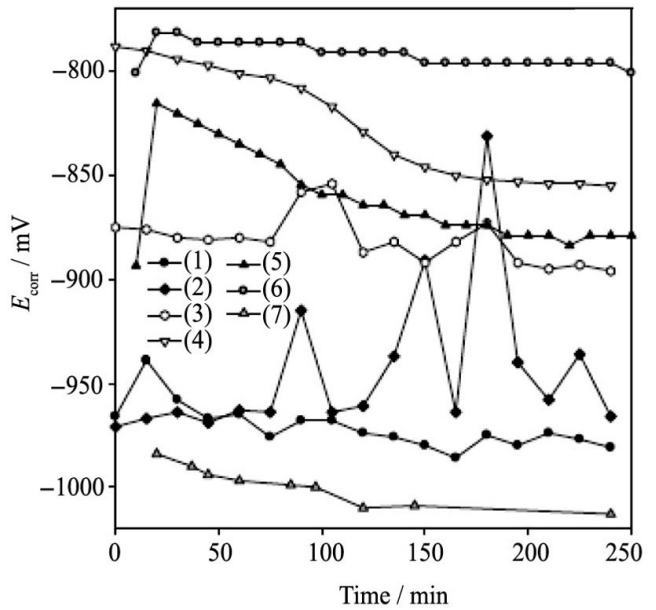

Fig. 2 Corrosion potential of the samples immersed in $0.025 \mathrm{~mol} / \mathrm{L}$

$\mathrm{NaCl}$ at different concentrations ( $\mathrm{mol} / \mathrm{L}$ ) of $\mathrm{La}(\mathrm{III})$ nitrate

(1) $3.3 \times 10^{-5}$; (2) $6.6 \times 10^{-5}$; (3) $1.0 \times 10^{-4}$; (4) $4.0 \times 10^{-4}$; (5) $1.0 \times 10^{-3}$; (6) $1.0 \times 10^{-2}$; (7) Blank

concentration increased from $3.0 \times 10^{-5}$ to $10^{-4} \mathrm{~mol} / \mathrm{L}$. In every case, $E_{\text {corr }}$ was shifted to more positive values comparing with the blank $(\sim-1.000 \mathrm{~V})$. Peaks observed in Fig. 2 could be attributed to active-passive transitions. When $\mathrm{La}$ (III) concentration increased to $10^{-3}$ or $10^{-2}$ $\mathrm{mol} / \mathrm{L}$, the corrosion potential was also shifted to less active values $\sim-0.100 \mathrm{~V}$. The oscillations presented in the corrosion potential when the $\mathrm{La}(\mathrm{III})$ concentration employed was $6.6 \times 10^{-5} \mathrm{~mol} / \mathrm{L}$ were due to the instability of the protective film which was suspected to a passivationbreak down-repassivation process.

The most striking effect of $\mathrm{La}(\mathrm{III})$ on $i_{\text {corr }}$ was appreciated at early immersion times. Steel corrosion rate was diminished after two hours of testing by lanthanum nitrate. However, the protective efficiency for $\mathrm{La}(\mathrm{III})$ concentration higher than $3.3 \times 10^{-5} \mathrm{~mol} / \mathrm{L}$ was, as a general rule, higher than $70 \%$. Steel corrosion rate did not vary significantly when $\mathrm{La}$ (III) was increased from $6.6 \times 10^{-5}$ to $4.0 \times 10^{-4} \mathrm{~mol} / \mathrm{L}$. A further increased of $\mathrm{La}(\mathrm{III})$ concen- tration up to $1.0 \times 10^{-2} \mathrm{~mol} / \mathrm{L}$, caused $i_{\text {corr }}$ to diminish a little bit more (Table 3 ).

\subsection{Observation and characterization of the exposed surface}

Galvanized steel panels that were in contact with the different La(III) solutions were observed by SEM after $24 \mathrm{~h}$ of immersion. They presented similar features. A more or less uniform film with a granule-like appearance was formed on the metallic surface together with agglomerates constituted by corrosion products (Fig. 3).

Table 3 Corrosion current of the samples immersed in $\mathrm{NaCl}$ $0.025 \mathrm{~mol} / \mathrm{L}$ and different concentrations of $\mathrm{La}(\mathrm{III})$ as a function of time

\begin{tabular}{cccc}
\hline \multirow{2}{*}{$\mathrm{La}\left(\mathrm{NO}_{3}\right)_{3}$ concentration/(mol/L) } & \multicolumn{3}{c}{ Corrosion current $/\left(\mu \mathrm{A} / \mathrm{cm}^{2}\right)$} \\
\cline { 2 - 4 } & $2 \mathrm{~h}$ & $5 \mathrm{~h}$ & $24 \mathrm{~h}$ \\
\hline 0 (blank) & 110.80 & 18.70 & 14.8 \\
$3.3 \times 10^{-5}$ & 8.32 & 5.72 & 7.97 \\
$6.6 \times 10^{-5}$ & 4.36 & 4.31 & 4.44 \\
$4.0 \times 10^{-4}$ & 3.19 & 4.95 & 5.30 \\
$1.0 \times 10^{-4}$ & 4.82 & 4.50 & 4.20 \\
$1.0 \times 10^{-3}$ & 2.87 & 3.09 & 1.01 \\
$1.0 \times 10^{-2}$ & 1.77 & 2.72 & 3.10 \\
\hline
\end{tabular}

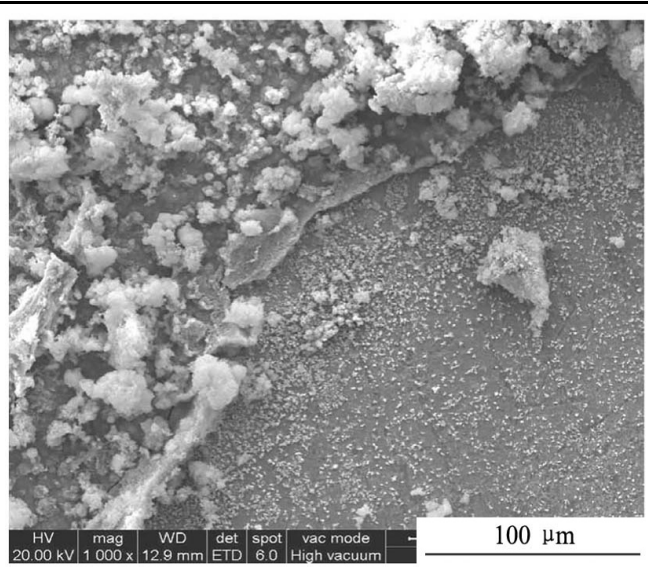

Fig. 3 SEM micrograph of protective film formed on galvanized steel after $24 \mathrm{~h}$ of immersion in $\mathrm{La}(\mathrm{III})$ solution 
The agglomerations were formed by zinc oxide partially carbonated (Fig. 4). Lanthanum could not be detected accurately in these formations because its signal was superimposed with the base line. The film underneath had similar composition. The granular morphology could be appreciated, in greater detail, in Fig. 5(a), corresponding to galvanized steel immersed in $6.6 \times 10^{-5} \mathrm{~mol} / \mathrm{L} \mathrm{La}(\mathrm{III})$ solution. Granules were formed on a more or less uniform film and rice grain-like morphology can be seen. These granules presented other morphologies (Fig. 5(b)). At higher concentration, the presence of $\mathrm{La}$ was detected

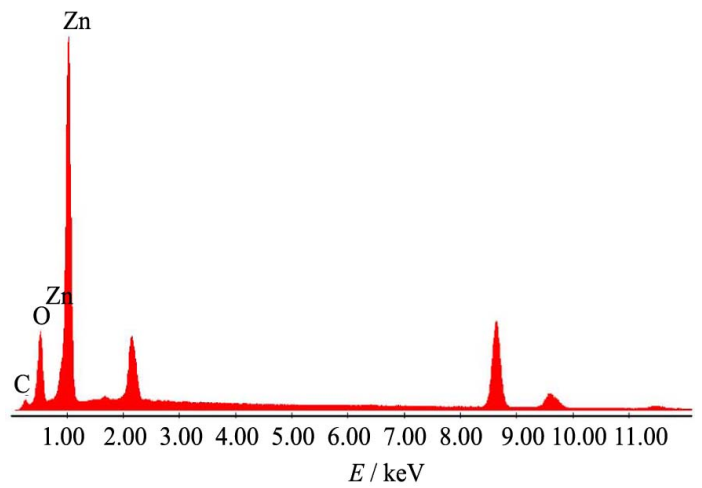

Fig. 4 EDX spectrum of agglomerations formed by zinc oxide partially carbonated
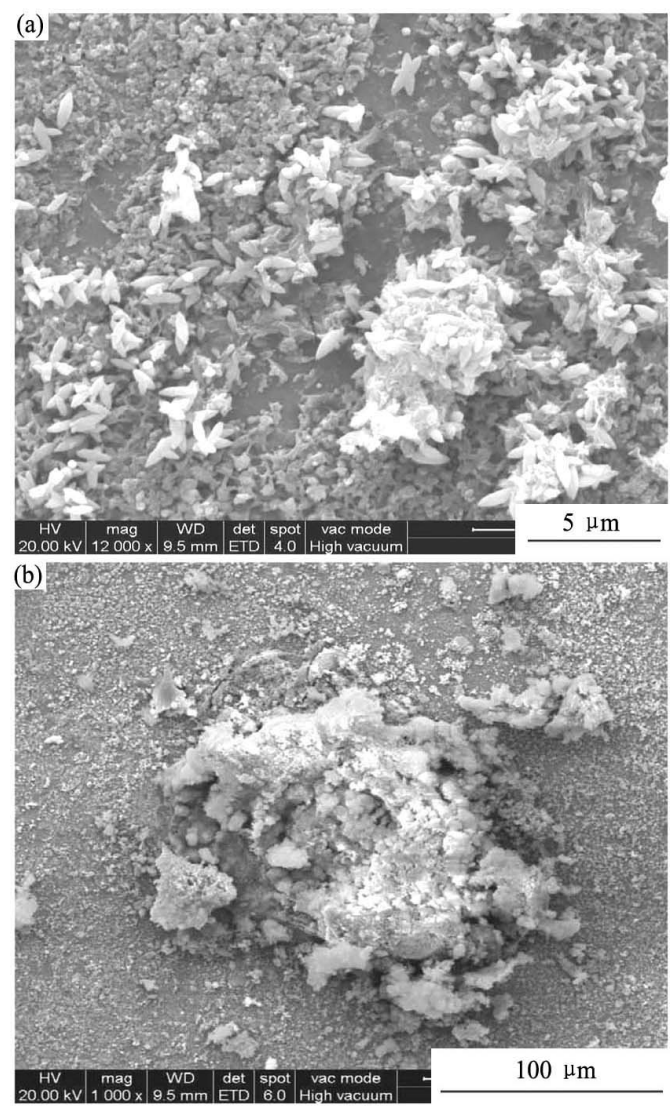

Fig. 5 SEM micrographs of film formed on galvanized steel immersed in $6.6 \times 10^{-5} \mathrm{~mol} / \mathrm{L}$

(a) Details of the granular morphology of the film; (b) Other morphologies in the globular formation $(\sim 2.4 \%)$ and in the granular texture film $(\sim 1.2 \%)$ (Fig. 6$)$ but no La was detected on the base film. Besides, some agglomerations with $\mathrm{Cl}$ $(0.7 \%)$ and $\mathrm{Fe}(1.2 \%)$ in low proportions were found.

When La concentration was raised, the number of the agglomerations per unit area diminished, however they did not disappear completely but the zinc oxide film grew in an ordered way (Fig. 7(a)). La content in the agglomerations and in the base film increased sensibly being in both cases close to $\sim 14 \%$. Petal-like formations grew on localized points of the surface (Fig. 7(b)) in such

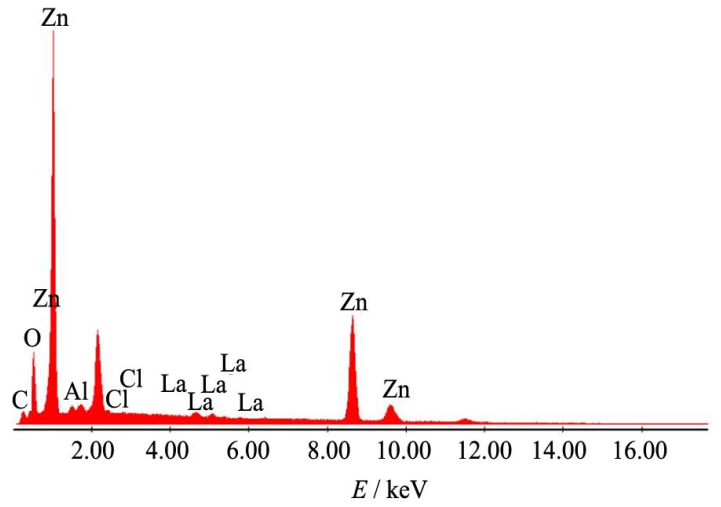

Fig. 6 EDX spectrum of globular formations
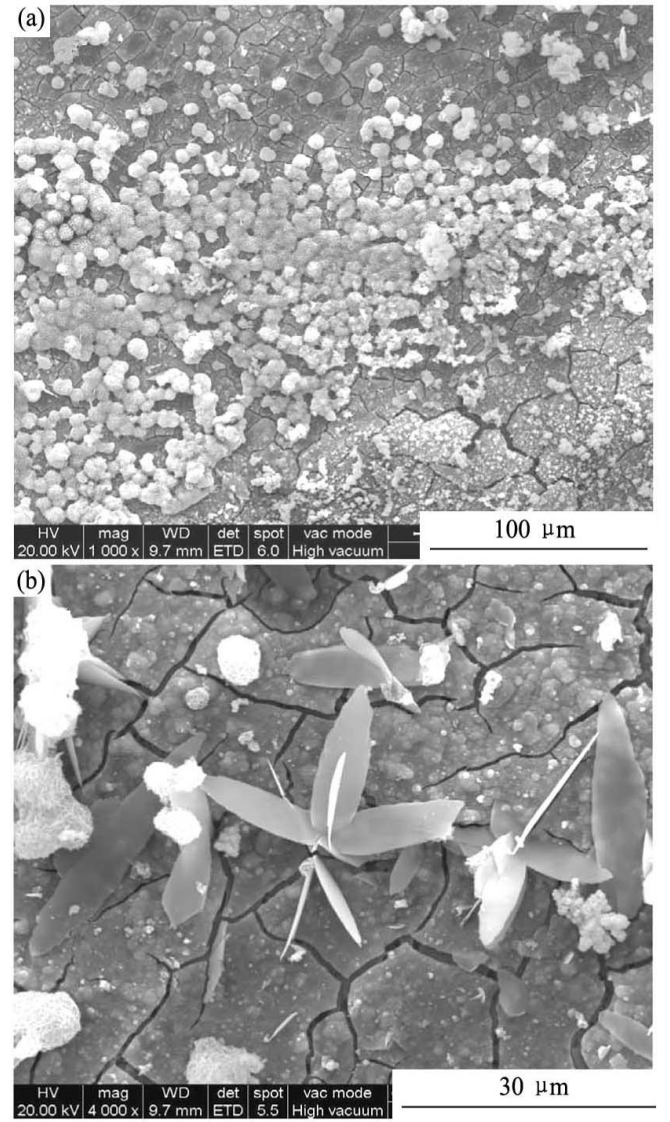

Fig. 7 SEM micrographs

(a) Granular appearance and agglomerations of the film formed on galvanized steel after $24 \mathrm{~h}$ of immersion in $1.3 \times 10^{-4} \mathrm{~mol} / \mathrm{L} \mathrm{La}$ solution; (b) Zinc oxide formations with a "petal" morphology 
a way that they did not cover the oxidized surface of galvanized steel. La concentration in these formations was found to be rather high $(\sim 22 \%)$. Fig. 8 shows the EDX spectra of these formations.

\subsection{Performance of anticorrosive paints in acceler- ated and electrochemical test}

\subsubsection{Salt spray chamber}

Except paint B1, all the paints blistered before $340 \mathrm{~h}$ but none of the panels showed corrosion. The size of the blisters varied from 6 (medium) to 2 (big) while the frequency degree was F (few) or M (medium). The size and frequency of the blisters increased with time in every panel, reaching the qualification $2 \mathrm{MD}$ (medium dense) or 2D (dense) after $2350 \mathrm{~h}$ of essay but the most important changes occurred at early exposure times. The higher blistering degree presented in the case of L1 and L3, regarding their control paints (B1 and B3, respectively) could be due to the incorporation of soluble species (La ions) that increase the osmotic pressure and enhance the entrance and accumulation of water. However, it must be taken into account that anticorrosive paints are never used alone but with a topcoat which highly restrains water penetration and, as a consequence blistering.

Corrosion of painted panels was detected after $1920 \mathrm{~h}$ of exposure but the rusted area was small $(\sim 0.03 \%$, qualification 9), except in the case of the panels coated with paint L1 (exchanged zeolite+zinc phosphate) which qualification was 8 (Table 4). However, this corrosion degree kept constant along time while in the other cases the rusted area increased and, concomitantly, the qualification diminished, especially in the case of the control panels (paints B1, B2 and B3) and in the case of L2, the paint with the exchanged zeolite. Panels with paints L1 and L3 were qualified with 8 after $2350 \mathrm{~h}$ of exposure. The results revealed that the best anticorrosive performance was achieved when the three pigments were included in the paint and that the presence of zinc phosphate can not be avoided but it may be significantly reduced with respect to the values suggested in the literatures $^{[26,27]}$.

\subsubsection{Ionic resistance}

The ionic resistance $\left(R_{\mathrm{i}}\right)$ did not vary significantly during

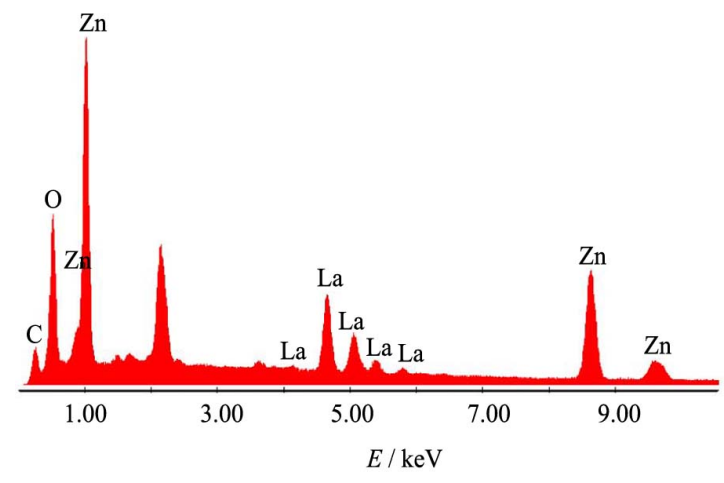

Fig. 8 EDX spectrum of the "petal" formations
Table 4 Rusting (ASTM D 610) and blistering (ASTM D 714) degrees of painted panels after the salt spray test (ASTM B 117)

\begin{tabular}{|c|c|c|c|c|c|c|c|c|c|c|c|c|}
\hline \multirow{3}{*}{ Paints } & \multicolumn{12}{|c|}{ Time of exposure $/ \mathrm{h}$} \\
\hline & \multicolumn{2}{|c|}{340} & \multicolumn{2}{|c|}{840} & \multicolumn{3}{|c|}{1536} & \multicolumn{2}{|c|}{1920} & \multicolumn{3}{|c|}{2350} \\
\hline & $\mathrm{R}^{\mathrm{a}}$ & $\mathrm{B}^{\mathrm{b}}$ & $\mathrm{R}^{\mathrm{a}}$ & $\mathrm{B}^{\mathrm{b}}$ & $\mathrm{R}^{\mathrm{a}}$ & $\mathrm{B}^{\mathrm{b}}$ & & $\mathrm{R}^{\mathrm{a}}$ & $\mathrm{B}^{\mathrm{b}}$ & $\mathrm{R}$ & $\mathrm{R}^{\mathrm{a}}$ & $\mathrm{B}^{\mathrm{b}}$ \\
\hline L1 & 10 & $6 \mathrm{~F}$ & 10 & $4 \mathrm{MD}$ & 10 & $2 \mathrm{M}$ & & 8 & $2 \mathrm{MD}$ & 8 & & MD \\
\hline L2 & 10 & $4 \mathrm{~F}$ & 10 & $2 \mathrm{MD}$ & 10 & $2 \mathrm{M}$ & & 9 & $2 \mathrm{MD}$ & 7 & 2 & MD \\
\hline L3 & 10 & $2 \mathrm{M}$ & 10 & $2 \mathrm{D}$ & 10 & $2 \mathrm{D}$ & & 9 & $2 \mathrm{D}$ & 8 & 3 & $2 \mathrm{D}$ \\
\hline B1 & 10 & 10 & 10 & $2 \mathrm{M}$ & 10 & $2 \mathrm{M}$ & & 9 & $2 \mathrm{MD}$ & 7 & 2 & MD \\
\hline B2 & 10 & $4 \mathrm{M}$ & 10 & $4 \mathrm{D}$ & 10 & $2 \mathrm{D}$ & & 9 & $2 \mathrm{D}$ & 6 & 5 & $2 \mathrm{D}$ \\
\hline B3 & 10 & $2 \mathrm{MD}$ & 10 & $2 \mathrm{D}$ & 10 & $2 \mathrm{D}$ & & 9 & $2 \mathrm{D}$ & 5 & 5 & $2 \mathrm{D}$ \\
\hline \multicolumn{3}{|c|}{$\begin{array}{l}{ }^{\mathrm{a}} \text { Rusting } \\
\text { degree }\end{array}$} & 10 & 9 & 8 & 7 & 6 & 5 & 4 & 3 & 2 & 1 \\
\hline \multicolumn{3}{|c|}{ Rusted area/\% } & 0 & 0.03 & 0.1 & 0.3 & 1 & 3 & 10 & 16 & 33 & 50 \\
\hline \multicolumn{13}{|c|}{${ }^{\mathrm{b}}$ Blistering degree } \\
\hline \multicolumn{2}{|c|}{ Frequency } & \multicolumn{2}{|c|}{$\begin{array}{l}\text { Dense } \\
\text { (D) }\end{array}$} & \multicolumn{5}{|c|}{ Medium dense (MD) } & \multicolumn{2}{|c|}{$\begin{array}{c}\text { Medium } \\
\text { (M) }\end{array}$} & & $\begin{array}{l}\text { Few } \\
\text { (F) }\end{array}$ \\
\hline \multicolumn{2}{|c|}{ Size } & \multicolumn{2}{|l|}{10} & \multicolumn{5}{|c|}{8} & \multicolumn{3}{|c|}{6,4} & 2 \\
\hline \multicolumn{2}{|c|}{ Comments } & \multicolumn{2}{|c|}{$\begin{array}{l}\text { No } \\
\text { blistering }\end{array}$} & \multicolumn{5}{|c|}{$\begin{array}{l}\text { Smaller size blister easily } \\
\text { seen by unaided eye }\end{array}$} & \multicolumn{4}{|c|}{$\begin{array}{l}\text { Progressively } \\
\text { larger sizes }\end{array}$} \\
\hline
\end{tabular}

the immersion period. Measured values were decreased from 5.3 to $1.9 \mathrm{~m} \Omega \cdot \mathrm{cm}^{2}$ as time went on. The area of direct contact between metal and electrolyte solution at the bottom of pores and fissures $\left(S_{\mathrm{p}}\right)$ could be calculated, as a rough approximation, with the equation proposed by Szauer ${ }^{[28]}$ :

$S_{\mathrm{p}}=d /\left(k^{*} R_{\mathrm{i}}\right)$

where $d$ is the coating thickness, $k$ the specific conductivity of the testing solution $(\mathrm{NaCl} 0.5 \mathrm{~mol} / \mathrm{L})$.

In all the cases the exposed area was rather small: $S_{\mathrm{p}} \sim$ $3.0-6.0 \times 10^{-8} \mathrm{~cm}^{2}$. The ionic resistance fluctuated between 2.8 and $5.6 \mathrm{~m} \Omega \cdot \mathrm{cm}^{2}$ indicating that paints had certain barrier effect. The employment of nanoclay did not improve this barrier effect.

2.5.3 Electrochemical noise

The mean corrosion noise potential oscillated between -0.93 and $-0.98 \mathrm{~V}$; no significant differences appeared in the behavior of the metal coated with the paints under study (Fig. 9). However, the mean coupling current oscillated in the cases of the panels painted with paints L1, L3, and B2 during $11 \mathrm{~d}$ of immersion probably due to active-passive transitions. After this time, the coupling current reached the lowest value. Then it began to increase slowly and till the end of the first fortnight of immersion. By this time, corrosion points appeared on all panels but the current density remained rather low, fluctuating around $9 \mu \mathrm{A} / \mathrm{cm}^{2}$, from the beginning of the essay (Fig. 10).

The noise resistance seems to evaluate the charge transfer process ${ }^{[29]}$. The $R_{\mathrm{n}}$ values (Fig. 11) for tested coating corrected by the area of the bare metal exposed directly to the electrolyte $\left(S_{\mathrm{p}}\right)$, were high pointing out 


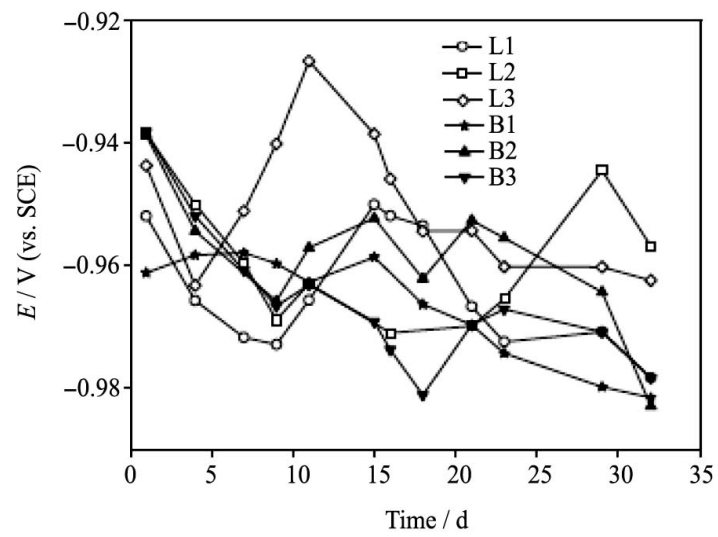

Fig. 9 Mean corrosion noise potential of the painted panels, as a function of time, in $0.5 \mathrm{~mol} / \mathrm{L} \mathrm{NaCl}$

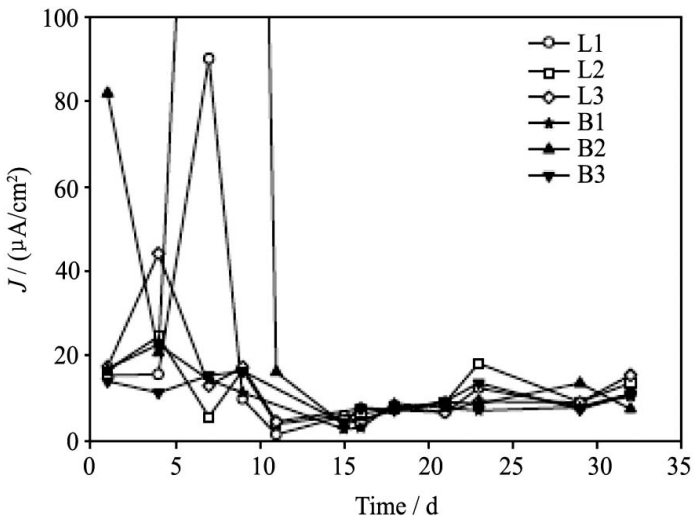

Fig. 10 Coupling current of the painted panels, as a function of time, in $0.5 \mathrm{~mol} / \mathrm{L} \mathrm{NaCl}$

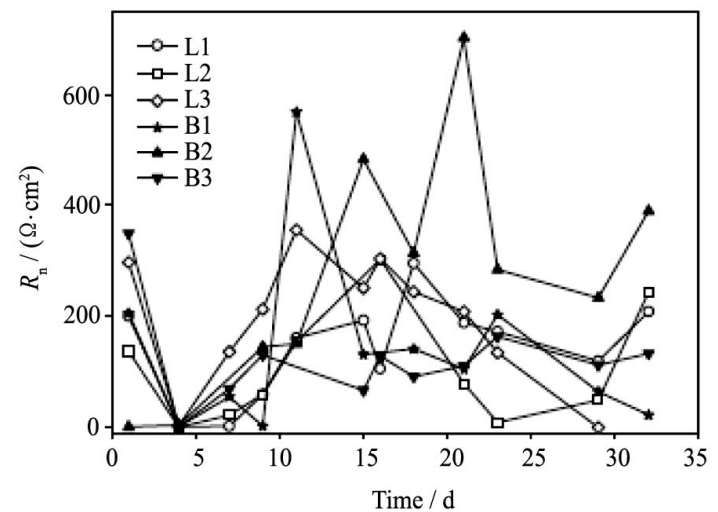

Fig. 11 Noise resistance of the painted panels, as a function of time, in $0.5 \mathrm{~mol} / \mathrm{L} \mathrm{NaCl}$

that the corrosion process was inhibited. As was mentioned before, the electrochemical active area was small $\left(\sim 3 \times 10^{-8}-4 \times 10^{-8} \mathrm{~cm}^{2}\right)$ and most of the surface was blocked by the coating. It is also possible that the kinetics and the reaction mechanism at the bottom of the pores and fissures contacting the metal base could be influenced by the formation of a corrosion products layer coupled with diffusion mechanisms through this layer ${ }^{[27]}$. Paints L which contained inhibitive substances presented $R_{\mathrm{n}}$ values slightly higher, especially at long exposure times.

\section{Conclusions}

The protective behavior of $\mathrm{La}(\mathrm{III})$ towards galvanized steel, at room temperature, did not depend on the concentration of the salt nor on the immersion time in $\mathrm{NaCl}$ solution when the concentration was comprised between $6.6 \times 10^{-5}$ and $4.0 \times 10^{-4} \mathrm{~mol} / \mathrm{L}$. Increasing $\mathrm{La}(\mathrm{III})$ concentration by two orders of magnitude diminished $i_{\text {corr }}$ only a little bit more. In brief, not much was gained with rather high concentration of $\mathrm{La}$ (III).

All the paints containing La exchanged zeolite protected galvanized steel in a satisfactory way, indicating that zinc phosphate content could be partially replaced by the modified zeolite. In addition, the protection of the substrate was achieved with very small amounts of lanthanum which allowed to replace important volumes of zinc phosphate in paint formulation.

It was also clear that La-exchanged zeolite introduced upgrade in the corrosion resistance of the epoxy paints.

Two thirds of the zinc phosphate content might be replaced by exchanged zeolite or by exchanged zeolite+ exchanged clay, without impairing paint performance.

Electrochemical tests supported the results obtained in the salt spray chamber.

Paint performance was improved incorporating zeolites and clays exchanged with passivating ions in epoxy paints.

Acknowledgements: The authors thanks to POLIDUR S.A. for providing the alkyd resin and Gonzalo Selmi for his technical support.

\section{References:}

[1] Odum E P. Ecología. Edited Nueva Editorial Interamericana, México DF, 1972, 117.

[2] Mc Grath J W, Quinn J P. Phosphate removal: a novel approach, Edited by Queen's University, Belfast, www.qub.ac.uk/envres/EarthAirwater/phosphate-removal. htm.

[3] Hare C. Extender pigments, Anatomy of paints, JPCL, 1990, 7(6): 43.

[4] Hare C H. Synergistic effects of wollastonite/inhibitor concentrations in epoxy metal primers. Journal of Protective Coatings and Linings, 1989, 6(9): 43.

[5] El-Sawy S. Egyptian kaolin as a filler and extender pigment for anticorrosive paints. Corrosion Prevention \& Control, 1994, (April): 31.

[6] Yeh J M, Liou S J, Lin C Y, Cheng C Y, Chang Y W, Lee K R. Anticorrosively enhance PMMA-clay nanocomposite materials with quaternary alkylphosphonium salt as an intercalating agent. Chem. Mater., 2002, 14: 154.

[7] Yeh J M, Liou S J, Lay C Y, Wu P C, Tsai T Y. Enhancement of corrosion protection effect in polyaniline via the formation of polyaniline-clay nanocomposite materials. Chem. Mater., 2001, 13: 1131.

[8] Trinh A T, To T X H, Vu K O, Dantras E, Lacabanne C, 
Oquab D, Pèbère N. Incorporation of an indole-3-butyric acid modified clay in epoxy resin for corrosion protection of carbon steel. Surf. Coat. Techn., 2008, 202(20): 4945.

[9] Bohm S, McMurray H N, Powell S M, Worsley D A. Novel environment friendly corrosion inhibitor pigments based on naturally occurring clay minerals. Materials and Corrosion, 2001, 52(12): 896.

[10] Kesavan D, Gopiraman M, Sulochana N. Green inhibitors for corrosion of metals: a review. Chem. Sci. Rev. Lett., 2012, 1(1): 1.

[11] Bethencourt M, Botana F, Calvino J, Marcos M, Rodriguez-Chacon M A. Lanthanide compounds as environmentally-friendly corrosion inhibitors of aluminium alloys: A review. Corr. Sci., 1998, 40: 1803.

[12] Barer R M. Zeolites and Clay Minerals as Sorbent and Molecular Sieves. New York: Academic Press, 1987. 221.

[13] Bernal S, Botana F J, Calvino J J, Marcos M, Pérez-Omil J A, Vidal H. Lanthanide salts as alternative corrosion inhibitors. J. Alloys Compd., 1995, 225: 638.

[14] Breck D W. Crystalline molecular sieves. J. Chem. Edu., 1964, 41: 678.

[15] Deya C, Romagnoli R, del Amo B. A new pigment for smart anticorrosive coatings. J. Coat. Technol. Res., 2007, 4(2): 167.

[16] Benthone ${ }^{\circledR} 107$, technical sheet, $<$ http://www.specialchem4 polymers.com/product-directory/ fillers_0_10079/index. aspx? $\mathrm{did}=0>$

[17] Welcher F J. Organic Analytical Reagents, Volume I. New York USA: D. Van Nostrand Company Inc, 1948. 311.

[18] Simões A M P, Carbonari R O, Di Sarli A R, del Amo B, Romagnoli R. An environmentally acceptable primer for galvanized steel: formulation and evaluation by SVET. Corr. Sci., 2011, 53: 464.

[19] Reichert D. Electrochemical noise measurements for determining corrosion rates. In: Kearns J R, Scully J R, Roberge P R, Reichert D L, Dawson J L, ed. Electrochemical Noise Measurements for Corrosion Applications.
1996. 79.

[20] Cottis R A. Interpretation of electrochemical noise data. Corrosion, 2001, 57(3): 265.

[21] Huet F. The electrochemical noise technique. In: P. Marcus, F. Mansfeld, ed. Analytical Methods in Corrosion Science and Engineering, CRC Taylor \& Francis, 2005. 507.

[22] Mabbutt S, Mills D J, Woodcock C P. Developments of the electrochemical noise method (ENM) for more practical assessment of anti-corrosion coatings. Progress in Organic Coatings, 2007, 59: 192.

[23] Tan Y J, Bailey S, Kinsella B. The monitoring of the formation and destruction of corrosion inhibitor films using electrochemical noise analysis (ENA). Corr. Sci., 1996, 38: 1681.

[24] Milán Z, Montalvo S, Ilangovan K, Monroy O, Chamy R, Weiland P, Sánchez E, Borja R. The impact of ammonia nitrogen concentration and zeolite addition on the specific methanogenic activity of granular and flocculent anaerobic sludges. J Environ Sci Health A Tox Hazard Subst Environ Eng, 2010, 45(7): 883.

[25] Carballo F. The zeolitas in Ecuador coast (Guayaquil) geology, characterization and applications. Universidad Politécnica de Madrid, 1-400, 2004.

[26] Gerhard A, Bittner A. Second generation phosphate anticorrosive pigments. Formulating rules for full replacement of new anti-corrosive pigments. J. Coat. Technol., 1986, 58(740): 59.

[27] Bittner A. Advanced phosphate anticorrosive pigments for compliant primers. J. Coat. Technol., 1989, 61(777): 114.

[28] Szauer T. Impedance measurements for the evaluation of protective nonmetallic coatings. Prog. Org. Coat., 1982, 10: 171 .

[29] Hernandez M, Genescá J, Uruchurtu J, Barba A. Correlation between electrochemical impedance and noise measurements of waterborne coatings. Corr. Sci., 2009, 51: 499. 